\title{
生物作用对海岸带泥沙运动的影响
}

\author{
龚政 ${ }^{1}$, 陈欣迪 ${ }^{1,2}$, 周曾 ${ }^{1,3^{*}}$, 葛再 ${ }^{1}$, 陈雪 ${ }^{1}$, 余锡平 ${ }^{2}$, 张长宽 ${ }^{1}$ \\ 1. 河海大学江苏省海岸海洋资源开发与环境安全重点实验室, 南京 210098; \\ 2. 清华大学水利水电工程系, 水沙科学与水利水电工程国家重点实验室, 北京 100084 ; \\ 3. 河海大学水文水资源与水利工程科学国家重点实验室, 南京 210098 \\ *联系人, E-mail: zeng.zhou@hhu.edu.cn
}

2020-03-19 收稿, 2020-07-21 修回, 2020-07-22 接受, 2020-07-23 网络版发表 国家杰出青年科学基金(51925905)和国家自然科学基金(41976156)资助

\begin{abstract}
摘要 海岸带泥沙运动输移及海岸地貌演变规律是海岸带海陆相互作用研究中重要的科学问题. 海岸带地区丰富 而活跃的生物因子与泥沙颗粒相互影响, 赋予了泥沙颗粒 “生物特性”, 深化了对传统海岸泥沙运动力学的认知, 相 关研究正逐渐成为研究热点. 本文针对海岸带泥沙运动中的生物作用, 结合国内外文献, 综述了植物、底栖动物、 微生物等生物因子在海岸带地区的分布特征、对海岸泥沙运动的贡献及其作用方式. 目前, 生物作用对海岸泥沙 运动影响的研究尚处于发展阶段, 大多为宏观层面的定性成果, 尚未形成完整的理论体系, 海岸泥沙与生物相互作 用的机理研究、泥沙运动及地貌演变预测模型的建立应成为今后研究的重点.
\end{abstract}

关键词海岸带, 泥沙的生物稳定性, 海岸植被, 底栖动物, 潮滩微生物

海岸泥沙运动输移及海岸地貌演变规律研究一直 是海岸带海陆相互作用研究中重要的科学问题. 作为海 陆相互作用最为频繁的区域, 海岸带生态系统特性具有 复合性、边缘性、活跃性等特点, 水动力、极端气候条 件、生物活动、人类活动等因子作用在一起, 造就了错 综复杂的泥沙运动规律及沉积物时空分布特点 ${ }^{[1]}$. 传统 的海岸泥沙研究体系主要考虑水动力和泥沙颗粒大小 等物理因素的影响 ${ }^{[2]}$. 近年来, 随着对生态环境问题认 识的不断加深, 生物作用在海岸带生态系统中扮演的重 要作用得到了越来越多的关注. 大量的野外观测数据及 室内试验研究证实, 海岸带生物(植物、动物、微生物 等)通过各种直接或间接作用影响着泥沙起动、输移、 沉降、固结等过程. 例如, 微生物通过分泌胞外聚合物 (extracellular polymeric substance, EPS)提高泥沙颗粒的 内聚力, 增强泥沙颗粒的抗蚀性 ${ }^{[3]}$; 潮滩植被通过削弱
水动力及截沙固滩提高滩面的稳定性 ${ }^{[4]}$; 潮滩底栖动物 通过摄食、掘穴等活动对底床产生生物扰动, 破坏完整 的底床结构 ${ }^{[5]}$. 这些多元的生物作用一方面赋予了泥沙 “生物特性”, 改变着泥沙的理化性质及运动特性, 另一 方面改造了海岸带的沉积/动力环境, 削弱/增强了引起 泥沙侵蚀的外部作用力.

海岸带作为海陆相互作用的前沿地带，在缓冲风 暴潮侵袭、保护生物多样性、降解环境污染等方面发 挥着重要作用 ${ }^{[6]}$. 研究生物作用对海岸带泥沙运动的影 响, 有助于丰富海岸泥沙运动特性的理论, 促进海岸动 力学、泥沙运动力学与生态环境学科的交叉, 促进新 兴学科“生物动力地貌学”(biomorphodynamics)的发展. 本文结合国内外文献，综述了植物、底栖动物及微生 物等生物因素在海岸带地区的分布特点及对海岸泥沙 运动的影响, 并分析了其作用方式, 而且针对研究现状

引用格式: 龚政, 陈欣迪, 周曾, 等. 生物作用对海岸带泥沙运动的影响. 科学通报, 2021, 66: 53-62 Gong Z, Chen X D, Zhou Z, et al. The roles of biological factors in coastal sediment transport: A review (in Chinese). Chin Sci Bull, 2021, 66: 53-62, doi: 10.1360/TB-2020-0291 
中的不足, 对今后的研究方向提出了展望.

\section{1 海岸带植被对泥沙输运的影响}

最常见的海岸带耐盐植被包括盐沼、红树林和海 草床, 广泛分布于全球超过 $80 \%$ 的温带、亚热带、热带 的河口海岸地区. 我国已知盐沼、红树林和海草床总 面积为 1500 4000 km ${ }^{2[7]}$, 它们为大量近岸生物提供了 宝贵的栖息地 ${ }^{[8]}$, 同时具有固碳、消浪、弱流、促淤 等十分重要的生态服务功能，被类比为“生态系统工程 师, ${ }^{[9,10]}$. 因此, 海岸植被与泥沙运动的相互作用是近年 来国内外学术研究的热点, 也是泥沙运动力学、海岸 地貌学、海岸工程学等领域的研究重点(图1). 以下从 海岸植被与泥沙运动的互馈过程分别进行介绍.

\section{1 海岸带植被对海岸动力的消减作用}

植被的根、茎、叶可以增大潮流通过时的摩擦力, 有效减小流速. 例如, 利用高分辨率流速仪对荷兰West Scheldt河口潮滩多个潮周期的观测表明，盐沼能使潮 流速降低1个数量级; 澳大利亚Corner Inlet的流速观测 结果显示, 潮流通过海草床后流速降低了 $40 \%$ 60\%; 我 国学者在福建云霄红树林国家自然保护区测量了红树 林与盐沼交错带的水动力、泥沙输运情况，发现潮流 速在经过红树林和盐沼后有极大的衰减，且此区域红 树林对流速的消减作用可达盐沼作用的 2 倍 ${ }^{[13]}$. 水槽试 验和现场观测表明，植被带的宽度以及植株密度是决 定植被弱流作用的关键参数, 弱流能力随着植被带宽 度和植株密度的增大而增强，且这种关系并非线 性 ${ }^{[14,15]}$. 此外, 值得一提的是, 植被类型、植株密度、
植被带宽度对水流的垂直剖面及紊动特性也有很大的 影响 ${ }^{[14]}$. 相对于刚性植物, 柔性植物在水流作用下易发 生弯曲来顺应水流流向, 进而减小对水流的阻力. 植物 淹没状态下, 水流紊动能和雷诺切应力减小; 而在非淹 没状态下, 紊动强度与植被密度以及距冠层边缘距离 呈反比. 植株密度的增加一般会增大对水流的阻力, 但 密度增大到一定值时, 水流阻力也会随着密度的增大 而减小. 此外, 植株密度对流速垂向剖面影响较大. 当 密度较小时, 垂向流速呈现近似对数形分布, 流速剖面 接近紊流边界层剖面; 而当密度较大时, 流速剖面更接 近混合层, 且在冠层顶部附近出现拐点. 通常植被带宽 度越大, 对水流的阻滞也越明显. 植被消浪作用相对于 光滩十分显著, 盐沼带中单位距离上波高的衰减是光 滩上的3 4倍 ${ }^{[16]}$. 江苏沿海实测数据表明, $200 \mathrm{~m}$ 的互花 米草盐沼带可使得波浪衰减达到 $90 \%{ }^{[12]}$; 欧洲科学家 在德国汉诺威长 $300 \mathrm{~m}$ 、宽 $5 \mathrm{~m}$ 、深7 $\mathrm{m}$ 的水槽中采用 真实盐沼植被进行了波浪衰减研究, 发现盐沼即使在 高水位也具有巨大的消浪作用，其导致的波高衰减可 达 $60 \%{ }^{[16]}$. 此外，现场观测表明，海草床在小波浪情况 下的波浪衰减效率也可达到 $50 \%{ }^{[17]}$ ，红树林由于高大 的枝干和茂密的冠层, 消浪效果甚至更强. 海岸植被因 强大的消浪、弱流作用正日益被海岸工程界应用到海 岸防护中.

\section{2 海岸带植被对泥沙运动的阻滞作用}

水动力的消减提供了一个相对低能的动力环境, 也可一定程度上促进黏性泥沙的絮凝，间接利于海岸 植被区域泥沙的落淤. 研究表明, 盐沼植被的茎、叶本
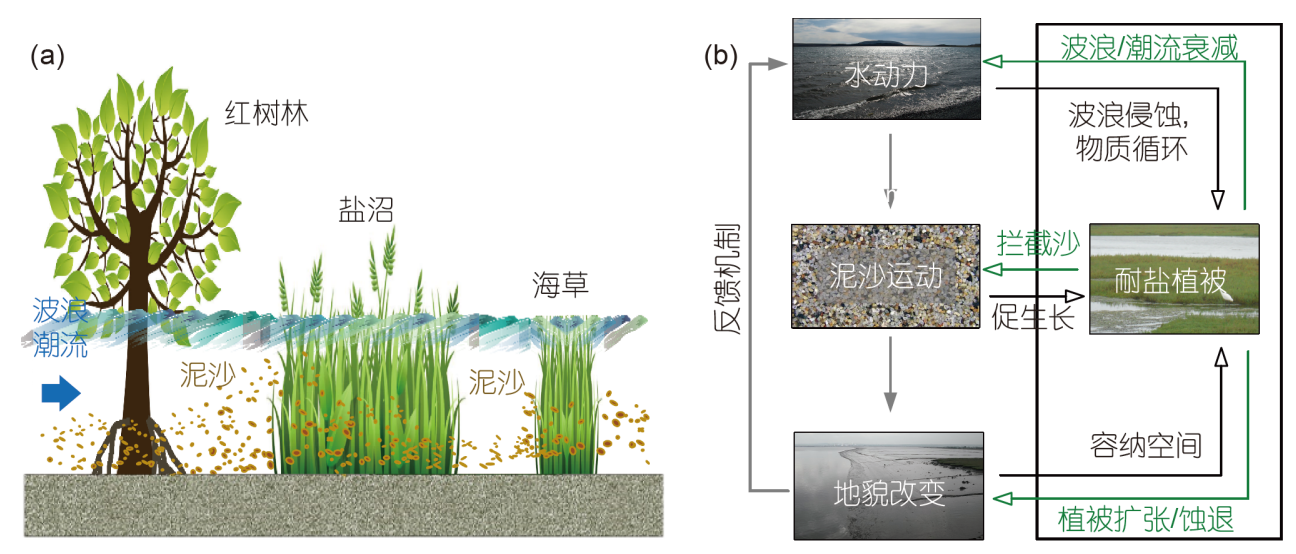

图 1 (网络版彩色)耐盐植被与泥沙相互作用示意图 $(\mathrm{a})^{[11]}$ 和海岸植被生物效应的动力地貌反馈过程示意图(b) ${ }^{[12]}$

Figure 1 (Color online) Schematic illustration of the influence of salt-tolerant vegetation on sediment transport (a) ${ }^{[11]}$ and schematic illustration of the morphodynamic feedback loop accounting for the effect of coastal vegetation (b) ${ }^{[12]}$ 
身也可直接、有效地拦截水体悬浮的泥沙和有机物, 阻止一部分泥沙的输运, 黏附在植被茎、叶上的泥沙 最终会因为重力或风吹雨打等环境因素而沉积 ${ }^{[4,12]}$. 英 国科学家现场观测发现, 盐沼植被的截沙效率可高达 $70 \%{ }^{[18]}$; 澳大利亚近岸观测数据表明, 海草床可使水体 悬沙浓度降低65\% 80\%. 海岸植被黏附泥沙能力的强 弱取决于植被类型、密度、茎叶形态结构、水体悬沙 浓度、水动力情况、泥沙特性等诸多因素．植被对泥 沙在底床的沉积也有一定作用，首先表现为使得植被 区泥沙细化，细颗粒泥沙被植被拦截后由于低能的环 境易于保持，且植被的根系也能一定程度上起到固定 泥沙的作用, 对潮沟边壁稳定等具有重要作用 ${ }^{[19]}$.

\section{3 海岸动力和泥沙运动对植被生长的反馈作用}

海岸植被对水动力的消减、泥沙的拦截等作用已 被广泛研究, 而环境条件如水动力、泥沙输运及地貌 演变情况也反作用于海岸植被(图1(b)), 这些动力过程 的反馈机制已逐渐被考虑进动力地貌数学模型, 但要 使模型具有广泛的适用性，还需要收集不同区域、不 同植被类型的密度、直径等数据，分析植被的空间分 布情况，选择适用于研究区域和本土植被类型的生物 量分布形式 ${ }^{[20]}$. 实测数据为生物动力地貌数学模型的 研发和应用提供了有利条件, 当下这一方面的研究也 是国际研究热点 ${ }^{[21]}$. 研究表明, 海岸植被处于动态变化 过程 ${ }^{[22]}$, 全球海平面上升、泥沙来源减少、风暴天气 频发以及大规模围星工程等因素对海岸植被的生存造 成了巨大的威胁 ${ }^{[23]}$. 近年来, 不少研究指出, 海岸植被 由于其弱流、固沙等作用可以在垂直向基本适应海平 面的上升，然而风浪侵蚀作用对植被前缘在水平向可 能会产生更大的威胁 ${ }^{[22]}$. 例如, 潮滩光滩向海方向的宽 度对于盐沼存亡有重要的影响, 较大的光滩宽度易于 提供较大的风场区域, 促进盐沼前缘波浪发育, 进而使 得前缘盐沼易受波浪侵蚀，且当光滩宽度达到一定阈 值, 或可造成不可逆转的盐沼侵蚀消亡 ${ }^{[24]}$. 总体而言, 泥沙来源丰富、波浪作用较弱、海平面上升速率较慢 的区域适宜海岸植被生长和扩张，但目前关于海岸动 力和泥沙运动对植被生长作用的认知还主要处于定性 层面, 定量化研究还处于发展阶段. 因此, 有必要加强 现场观测和实验室试验, 推进定量化研究, 进而建立海 陆耦合、环境-植被动力过程耦合的动力地貌模型, 这 对于预测海岸植被的未来演变具有重要的意义 ${ }^{[25]}$. 海 岸植被影响下的泥沙输运是这类模型的桥梁，连接着
水动力、地貌演变 ${ }^{[26]}$, 是认知海岸带地貌演变的基础 和前沿.

\section{2 海岸带底栖动物对泥沙输运的影响}

底栖动物是指全部或大部分时间生活于水体底部 的水生动物群 ${ }^{[27]}$. 一般将不能通过 $500 \mu \mathrm{m}$ 孔径篎网的 动物称为大型底栖动物. 在大部分水体中, 大型底栖动 物的生物量在底栖动物中超过 $90 \%$, 因此在生物动力地 貌学中, 大型底栖动物的影响一直是研究重点. 底栖动 物通过生物扰动作用影响海岸带沉积物的物理化学进 程, 参与整个生态系统物质循环和能量流动 ${ }^{[28]}$, 是海岸 带生态系统的重要组成部分.

\section{1 海岸带底栖动物分布及影响因素}

海岸带底栖动物分布广阔, 种类繁多, 主要由环节 动物 (多毛类、寡毛类等)、线虫动物、软体动物 (螺 类、蛙类等)、甲壳动物 (蟹类、虾类等)、单肢动物 (昆虫等)构成，低潮滩区多以塞毛类、多毛类为主，而 高潮滩区的优势物种则以甲壳类为主. 在空间上, 底栖 动物的物种分布与温度、盐度、底质、高程、水文条 件等非生物因子以及植被、种内种间竞争等生物因子 及人类活动有关, 以下分别进行简要介绍.

温度在大的地理尺度上是物种分布的主导因子 ${ }^{[29]}$, 盐度则是小尺度上影响底栖动物分布的主要因素 ${ }^{[30]}$. 潮滩底质对底栖动物分布有显著影响. 砂质底床上的 底栖生物量常常较低, 而淤泥和黏土富含沉积物碎屑, 有机质含量高, 生物量较大. 此外, 高程不仅影响了淹 水时间、光照强度和底质性质，还使得部分底栖动物 暴露从而增加被捕食概率 ${ }^{[31]}$. 水文条件影响因子主要 包括潮位、水深和流速等，底栖动物的密度随潮位的 增加而减少, 大多随着水深的增加而递减 ${ }^{[22]}$; 流速较高 的区域对洞穴扰动较大, 因而底栖动物的数量较少 ${ }^{[33]}$. 植被为底栖动物提供隐蔽场所，防止其遭受捕食者的 袭击, 同时碎屑还能提供食物; 密度较高的植被能够减 小水分蒸发，保持阴凉，为底栖动物提供合适的生境. 另外，种内种间竞争也是影响底栖动物分布的主要因 素 ${ }^{[34]}$. 随着经济发展, 人类活动对潮滩环境的影响越来 越大. 过度捕捞会导致某一底栖动物数量骤减, 影响群 落结构, 围堲会降低底栖动物的数量与多样性, 海平面 上升则威胁着整个海岸带生态系统 ${ }^{[35]}$. 值得一提的是, 大型底栖动物的种群密度和群落结构在时间尺度上也 存在差异, 随季节变化较明显, 冬季最低, 经过夏季的 
繁殖和生长, 常在夏末秋初密度达到最高, 而多样性在 不同季节间没有明显差异 ${ }^{[36]}$.

\section{2 海岸带底栖动物对沉积物的扰动作用}

海岸带底栖动物通过摄食、掘穴等生理活动直接 或间接地影响着沉积物的结构和性质, 严重的甚至使 层理变形或断裂以致位移. 植食性底栖动物常以植物 根系为食或在掘穴的过程中打断植物根系, 导致植物 死亡 ${ }^{[37]}$. 植物的根系能够较好地拦截泥沙、减缓流 速、固结土壤、促进淤积 ${ }^{[38]}$, 因此底栖动物可间接削 弱土体的整体性, 降低土体强度和抗侵蚀性. 底栖动物 常挖掘洞穴或管道以躲避捕食者, 缓解高温缺水的压 力, 在掘穴的过程中, 底栖动物的扰动使得沉积物孔隙 率增加, 结构更松散 ${ }^{[39]}$, 同时将底层的泥沙带到表层, 使得表层沉积物细化, 含水率增高, 强度降低. 此外, 洞穴还会增大潮滩表面积, 提高土壤含氧量, 加上摄食 过程中产生的有机碎屑, 增强了有机物的分解.

底栖动物洞穴开口有大有小, 漏斗形的开口方式 在涨潮期间能够捕捉泥沙，但洞穴捕获沉积物碎屑的 数量远远小于底栖动物挖掘维护洞穴掘出的沉积物 量 $^{[40]}$; 开口较小的洞穴涨潮时常被堵住, 但挖掘洞穴带 出的泥沙在高潮时常被潮流带走. 洞穴作为垂直交换 通道, 每天垂直运移的沉积物数量可观. 在北美盐沼开 展的研究发现，招潮蟹的沉积物挖掘量可达到120 $160 \mathrm{~cm}^{3} \mathrm{~m}^{-2} \mathrm{~d}^{-1[41]}$; Iribarne等人 ${ }^{[42]}$ 在巴西和阿根廷之间 的河口地区测出, 螃蟹每天的掘出量达 $5 \mathrm{~kg} / \mathrm{m}^{2}$.

滩面上与生物活动伴生的微地貌广泛存在, 包括 粪球、小土墩、凹坑等. 底栖动物在进食后, 把不能消 化的物质排泄出, 形成真粪球, 在挖掘维护洞穴的过程 中形成假粪球，这些颗粒物都很容易被波浪掀起进而 被潮流带走 ${ }^{[43]}$. 底栖动物掘穴过程中的产物或波浪引 起的向上渗流沿管道流动时带出细粒土形成小土墩, 它们或被潮流带走形成凹坑, 或经历若干个潮周期后 积聚在沉积物表层, 成为表层沉积物的一部分, 增加了 表层沉积物的粗粘度 ${ }^{[44]}$.

\section{3 海岸带底栖动物对沉积物稳定的增强作用}

Crusius等人 ${ }^{[45]}$ 利用同位素测算出底栖动物的扰动 深度为 $25 \sim 35 \mathrm{~cm}$, 常常能达到地下水位附近, 当下层透 水性比上层土壤高, 同时生物洞穴和下层土层连通时, 洞穴的存在还能够充当优先排水通道, 改变了土体的 渗透性 ${ }^{[39]}$. 波浪是海床垂直渗流的动力, 固有频率的波
浪荷载会使海床产生累积超静孔隙水压力. 生物洞穴 中的渗流对波浪的衰减有一定的影响, 同时生物扰动 改变了土体的性质, 减小了土体孔隙水压力的累积, 有 利于释放能量, 增加沉积物的固结程度, 缓解大风浪引 起的土层渗流液化 ${ }^{[46]}$. 部分底栖动物在维护洞穴结构 的过程中分泌黏液，将沉积物黏合成管状或丝状团粒, 能有效地提高沉积物的稳定性; 当黏液释放到水体中, 能够增加水中悬浮颗粒之间的黏聚力而形成大颗粒絮 团 ${ }^{[3]}$; 含有机物和胶黏体的粪便也能使沉积物胶结成团 块, 降低沉积物在系统中的移动性和流失, 增加沉积物 的稳定性. 部分研究认为, 生物扰动在大尺度上 $(50 \mathrm{~m}$ 以上)使沉积物趋于稳定 ${ }^{[47]}$. 因此, 底栖动物对沉积物 稳定性的影响具有双重效应, 仍有待深人研究(图2).

\section{3 海岸带潮滩微生物对泥沙性质及运动特性 的影响}

从微观视角看, 潮滩上丰富的微生物体系的存在 使得潮滩近底边界层内发生着复杂的物理-化学-生物 过程, 其对潮滩微地貌的塑造作用是一个新的研究难 点 ${ }^{[48,49]}$. 在挟沙水体中, 泥沙颗粒在水流的作用下起动 (erosion)、输移(transportation)、沉降(deposition)、固 结(consolidation), 形成“ETDC”循环，对河口海岸的物 质输运和地貌演变有重大意义. 微生物系统通过对泥 沙颗粒的附着、包裹, 对颗粒间的架桥黏结, 以及对底 床的覆盖保护等作用, 调节着泥沙运动的“ETDC”循 环 $^{[50]}$.

\section{1 海岸带潮滩微生物及其生物膜}

当广泛存在于海水中的细菌、藻类等微生物吸附 于固体表面(如潮间带泥沙颗粒、植被根茎等)时, 会分 泌一种被称为胞外聚合物的黏性物质. EPS的主要成分 与微生物的胞内成分相似, 为高分子聚合物, 主要为多 糖和蛋白质. 微生物及其分泌的EPS共同组成了生物 膜. 海岸带潮滩生物膜的存在在滩面泥沙与空气/水体 之间形成了一道天然的保护屏障, 被相关学者称为潮 滩的“skin”, [50]. 潮滩生物膜在滩面的固-液/固-气交界面 上调节着众多复杂的物理、化学和生物过程, 在潮滩 系统的结构、功能和动力方面扮演着重要的角色. 由 于生物膜中微生物优势种群的不同, 潮滩生物膜可能 展现出多种不同的表观特征, 最为典型的为呈现棕褐 色的硅藻类生物膜. 潮滩微生物受潮动力的影响, 往往 形成区别于河流中恒定流环境下的独特生长模式. 例 


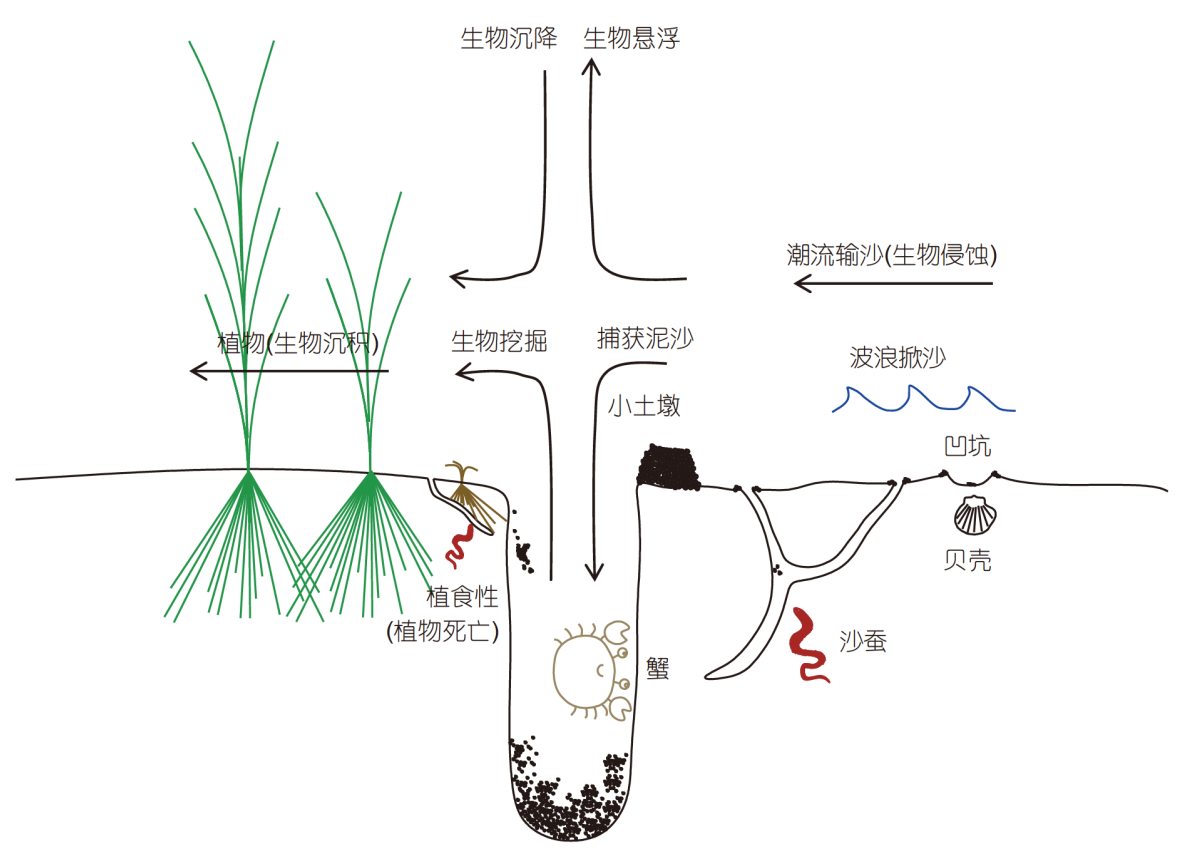

图 2 (网络版彩色) 底栖动物对沉积物的扰动机制

Figure 2 (Color online) The disturbance mechanism of benthic animals to sediments

如, 受每日涨落潮的作用, 当潮流流速较大时, 为了避 免暴露于较强的动力环境下, 具有移动性的硅藻常从 滩面向下迁移至底床的次表层; 当落潮露滩时, 若光照 过强, 为避免高强度的辐射给细胞带来的损害, 硅藻也 可能由潮滩表面向下迁徙 ${ }^{[51]}$.

\section{2 海岸带泥沙的生物稳定性}

由于生物膜的黏附而抑制泥沙侵蚀的效应最早被 国外学者Paterson和Daborn ${ }^{[52]}$ 定义为“生物稳定性” (biostabilisation), 并逐渐在国际上受到关注 ${ }^{[53]}$.

近几十年来, 关于潮滩生物稳定性的研究表明, 生 物膜与泥沙的结合能力不仅受所处环境(水动力、水 体盐度等)的影响, 还受EPS组分(多糖和蛋白的比值 等)、微生物的种类(菌类、藻类、菌藻共生体系)等因 子的影响，而这些微生物的生理指标又取决于其所处 的环境条件 ${ }^{[54]}$. Gerbersdorf等人 ${ }^{[55]}$ 对研究区域潮间带 泥沙的多个指标进行了检测，包括容重、含水率、矿 物组成、叶绿素 $\mathrm{a}$ 浓度、EPS含量、临界起动切应力 等, 认为海岸泥沙的稳定性可以由泥沙的物理、化 学、生物指标通过一定的组合方式很好地表达. 由此 可见，泥沙的沉积因子和生物因子之间有着密不可分 的关联, 在水动力作用下相互影响, 共同决定了海岸带 泥沙的稳定性.
研究表明, 淡水环境下(如河道中)生物膜对增加河 床抗侵能力的作用显著. Tolhurst等人 ${ }^{[56]}$ 在含有黏性组 分的底沙上培养硅藻生物膜, 观察到 $45 \mathrm{~d}$ 的生长期内, 泥沙的湿密度、含水率、临界起动切应力均发生了明 显改变. Stone等人 ${ }^{[57]}$ 基于室内环形水槽试验研究发现, 不同沉积时间对河流中天然黏性泥沙冲刷特性的影响 远大于对相同粒径模型沙的影响. 研究者认为, 这一差 异的产生原因为生物膜的作用, 即沉降时间越长, 越有 利于生物膜的生长, 生物黏性的增加提高了底床的抗 侵能力. 在盐水环境下 (如潮滩上), 生物膜的形成不仅 能提高底沙的临界起动切应力, 而且因泥沙具有多孔 介质的特性，生物膜可在泥沙孔隙间形成垂向网状结 构，具有向底床更深层“渗透”的能力 ${ }^{[3,58]}$. 生物膜沿底 床深度方向的分布将对次表层泥沙的冲刷产生持续的 抑制作用, 进一步降低水体中的悬沙浓度, 继而对泥沙 的输运产生重要影响(图3 $)^{[3]}$.

\section{3 海岸带泥沙生物稳定性的影响因素及数学表达}

生物稳定性的产生机理复杂，但一般认为在水流 作用下, 水中的微生物通过其分泌物EPS与泥沙颗粒黏 连，生物膜包裹泥沙表面、填充颗粒间孔隙并提供更 多离子吸附点位 ${ }^{[59,60]}$, 使得泥沙除了理化黏性以外, 还 具有生物黏性, 继而导致泥沙运动特性的改变. 生物膜 


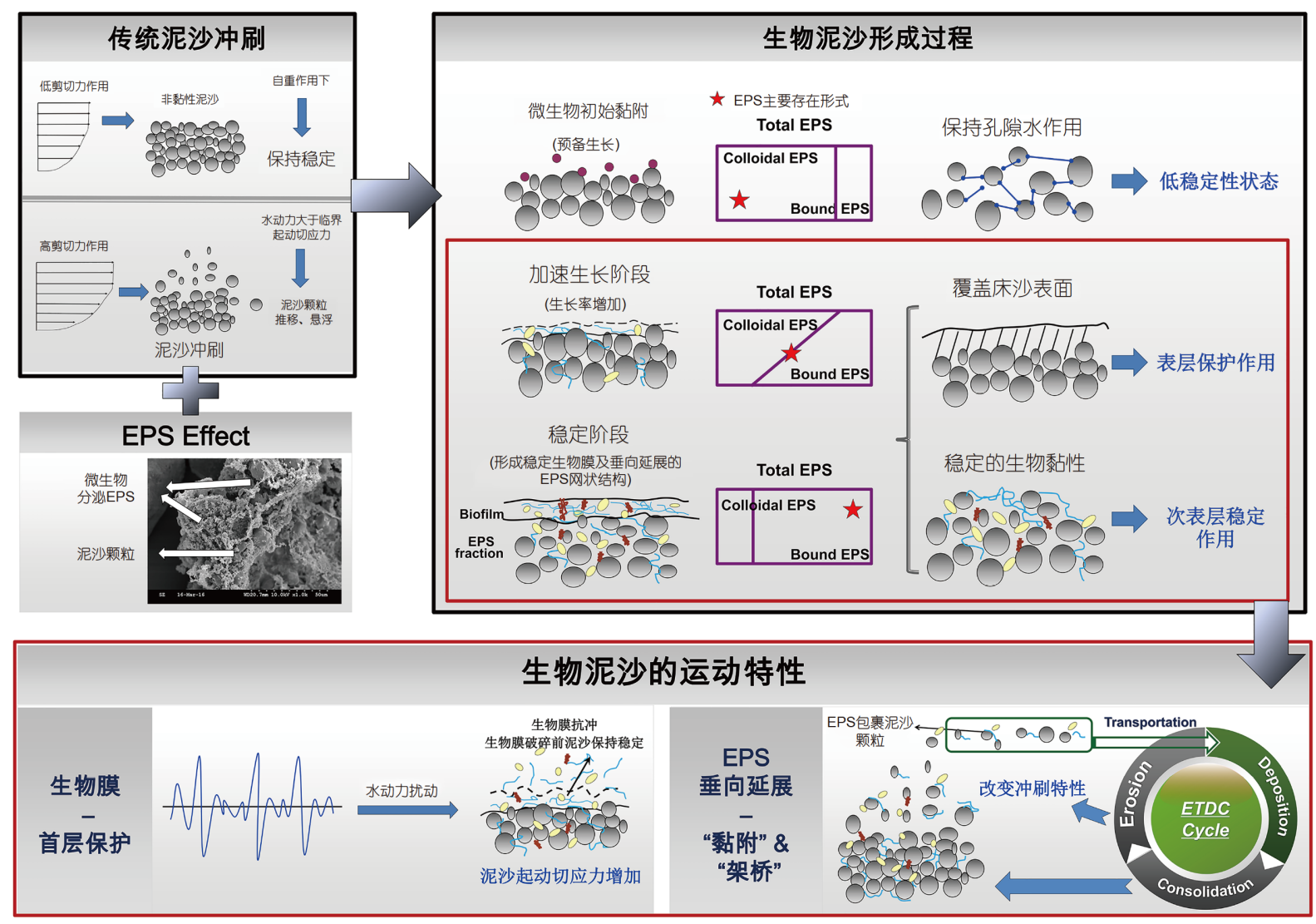

图 3 (网络版彩色)生物膜-泥沙的形成及其对水动力的响应机制 ${ }^{[3]}$

Figure 3 (Color online) The formation of biofilm-sedimentary system and its response to hydrodynamic force ${ }^{[3]}$

黏附能引起泥沙抗侵强度的显著提高，如表面生长硅 藻生物膜后细沙的临界起动切应力可提高 $5 \sim 8$ 倍 ${ }^{[50]}$. 方 红卫等人 ${ }^{[61]}$ 根据淡水环境下培养生物膜后泥沙的起动 实验数据, 将生物膜作用产生的黏连力引人颗粒受力 分析中，得到了生物膜生长后泥沙颗粒的起动流速计 算公式. 然而, 生物膜在泥沙上的生长与环境条件关系 密切, 在多因子共同作用的复杂潮滩生境下, 不同环境 条件如温度、光照强度、营养盐浓度、水动力条件、 微生物群落、植被根系、底栖动物等的组合影响下, 生物膜与泥沙黏附的稳定性、所形成的生物膜-泥沙 的抗侵强度将发生较大改变 ${ }^{[24,62]}$. 例如, 就水动力而言, 潮滩系统一个主要的动力特征是受大、小潮影响, 在 相应的高、低切应力之间循环变化形成周期性扰动. 因此，生长于潮滩地区的微生物群落因长期适应这种 动态变化的水动力环境, 导致生物膜-泥沙的形成及其 侵蚀特性的演变规律，与大量现有的在恒定流、淡水 条件下进行短期培养得到的研究结果差异显著. 因此, 针对海岸带潮滩生境中微生物系统的物种类群与群落
结构、代谢方式及其与潮滩特殊自然环境相互作用和 演化的机制, 仍有待进一步研究. 在众多复杂的环境因 素中, 哪些是关键性的影响因子, 海岸带泥沙生物稳定 性应如何定量描述与数学表达, 还需建立在大量野外 观测数据的基础上，利用多学科交叉的方法进行综合 分析.

\section{4 结论与展望}

河口海岸地区的泥沙运动输移不仅直接影响海岸 地貌演变, 还具有营养盐循环、污染物迁移降解、生 态湿地的建立和维护等多项生态服务功能. 随着对生 态和环境问题认识的不断提升，基于理化过程为主的 传统海岸泥沙运动力学的研究视角逐渐向生物、生态 的方向发展, 为海岸泥沙运动及地貌演变规律的研究 打开了新的篇章. 目前, 国内外对泥沙生物稳定性的研 究尚处于认识现象及规律解读的发展阶段, 大多从宏 观角度研究各种生物因素、环境因素与泥沙性质及运 动特性的相互作用关系, 部分研究尝试运用模型量化 
生物因素对海岸泥沙运动及海岸地貌演变的影响，相 关研究尚未形成完整的理论体系. 根据目前的研究现 状, 建议未来围绕以下几方面进行研究.

(1) 通过野外观测及采样分析，利用相关分析、排 序分析等数据分析手段，进一步深化对盐沼植物、底 栖动物、微生物等生物作用与泥沙运动相互耦合过程 的认识, 并分析环境因素(营养盐、光照、水动力等)与 生物及泥沙运动相互作用的关联性.

（2）在现象认识与规律解读的基础上, 结合现场观
测与室内试验定量描述生物作用下泥沙理化性质及运 动输移特性的变化规律, 借助生态学、物理、化学、 海岸动力学等多学科知识从微观角度揭示这种变化的 成因及机理.

(3) 针对海岸泥沙运动中的生物作用与泥沙运动力 学各种理化参数的相互影响, 改进传统研究体系中基于 理化过程的海岸泥沙运动力学方程, 并将研究结果应用 到海岸地貌演变及生态栖息地的建立和维护、污染物 迁移释放、极端气候防护等海洋生态文明建设中.

\section{参考文献}

1 Dalrymple R W, Choi K. Morphologic and facies trends through the fluvial-marine transition in tide-dominated depositional systems: A schematic framework for environmental and sequence-stratigraphic interpretation. Earth-Sci Rev, 2007, 81: 135-174

2 Jepsen R, Roberts J, Lick W. Effects of bulk density on sediment erosion rates. Water Air Soil Poll, 1997, 99: 21-31

3 Chen X D, Zhang C K, Paterson D M, et al. Hindered erosion: The biological mediation of noncohesive sediment behavior. Water Resour Res, 2017, 53: 4787-4801

4 Li H, Yang S L. A review of influences of saltmarsh vegetation on physical processes in intertidal wetlands (in Chinese). Adv Earth Sci, 2007, 22: 39-47 [李华, 杨世伦. 潮间带盐沼植物对海岸沉积动力过程影响的研究进展. 地球科学进展, 2007, 22: 39-47]

5 Tang Y J. Study on the community ecology of macrobenthic fauna in the wetland of the Zhanjiang Mangrove Nature Reserve (in Chinese). Doctor Dissertation. Guangzhou: Sun Yat-sen University, 2007 [唐以杰. 湛江红树林自然保护区湿地大型底栖动物群落生态学研究. 博士学位论文. 广州: 中山大学, 2007]

6 de Groot R S, Wilson M A, Boumans R M J. A typology for the classification, description and valuation of ecosystem functions, goods and services. Ecol Econ, 2002, 41: 393-408

7 Tang J W, Ye S F, Chen X C, et al. Coastal blue carbon: Concept, study method, and the application to ecological restoration. Sci China Earth Sci, 2018, 61: 637-646 [唐剑武, 叶属峰, 陈雪初, 等. 海岸带蓝碳的科学概念、研究方法以及在生态恢复中的应用. 中国科学: 地球科学, 2018, 48: 661-670]

8 Barbier E B, Hacker S D, Kennedy C, et al. The value of estuarine and coastal ecosystem services. Ecol Monogr, 2011, 81: 169-193

9 Bouma T J, van Belzen J, Balke T, et al. Identifying knowledge gaps hampering application of intertidal habitats in coastal protection: Opportunities \& steps to take. Coast Eng, 2014, 87: 147-157

10 Zhang R S, Shen Y M, Lu L Y, et al. Formation of Spartina alterniflora salt marsh on Jiangsu coast, China (in Chinese). Oceanol Limnol Sin, 2005, (4): 358-366 [张忍顺, 沈永明, 陆丽云, 等. 江苏沿海互花米草(Spartina alterniflora)盐沼的形成过程. 海洋与湖沼, 2005, (4): 358-366]

11 Friess D, Sidik F. Dynamic Sedimentary Environments of Mangrove Coasts. Elsevier, 2020, https://www.elsevier.com/books/dynamicsedimentary-environment-of-mangrove-coasts/friess/978-0-12-816437-2

12 Zhou Z, Ye Q, Coco G. A one-dimensional biomorphodynamic model of tidal flats: Sediment sorting, marsh distribution, and carbon accumulation under sea level rise. Adv Water Resour, 2016, 93: 288-302

13 Chen Y, Li Y, Thompson C, et al. Differential sediment trapping abilities of mangrove and saltmarsh vegetation in a subtropical estuary. Geomorphology, 2018, 318: 270-282

14 Nepf H M. Flow and transport in regions with aquatic vegetation. Annu Rev Fluid Mech, 2012, 44: 123-142

15 Tinoco R O, Coco G. A laboratory study on sediment resuspension within arrays of rigid cylinders. Adv Water Resour, 2016, 92: 1-9

16 Möller I, Kudella M, Rupprecht F, et al. Wave attenuation over coastal salt marshes under storm surge conditions. Nat Geosci, 2014, 7: 727-731

17 Ondiviela B, Losada I J, Lara J L, et al. The role of seagrasses in coastal protection in a changing climate. Coast Eng, 2014, 87: 158-168

18 Mudd S M, D'Alpaos A, Morris J T. How does vegetation affect sedimentation on tidal marshes? Investigating particle capture and hydrodynamic controls on biologically mediated sedimentation. J Geophys Res, 2010, 115: F3029

19 Gong Z, Zhao K, Zhang C, et al. The role of bank collapse on tidal creek ontogeny: A novel process-based model for bank retreat. Geomorphology, 2018, 311: 13-26

20 Gong Z, Bai X B, Jin C, et al. A numerical model for the cross-shore profile evolution of tidal flats based on vegetation growth and tidal processes (in Chinese). Adv Water Sci, 2018, 29: 877-886 [龚政, 白雪冰, 靳闯, 等. 基于植被和潮动力作用的潮滩剖面演变数值模拟. 水科学进展, 2018, 29: 877-886] 
21 Wiberg P L, Fagherazzi S, Kirwan M L. Improving predictions of salt marsh evolution through better integration of data and models. Annu Rev Mar Sci, 2020, 12: 389-413

22 Kirwan M L, Megonigal J P. Tidal wetland stability in the face of human impacts and sea-level rise. Nature, 2013, 504: 53-60

23 Woodroffe C D, Rogers K, McKee K L, et al. Mangrove sedimentation and response to relative sea-level rise. Annu Rev Mar Sci, 2016, 8: 243-266

24 Mariotti G, Fagherazzi S. Modeling the effect of tides and waves on benthic biofilms. J Geophys Res Biogeosci, 2012, 117: G4010

25 Fagherazzi S, Kirwan M L, Mudd S M, et al. Numerical models of salt marsh evolution: Ecological, geomorphic, and climatic factors. Rev Geophys, 2012, 50: G1002

26 Wang Y P, Zhang R S, Gao S. Geomorphic dynamic response of salt marsh-tidal gully. Chin Sci Bull, 1999, 44: $544-549$ [汪亚平, 张忍顺, 高抒. 论盐沼-潮沟系统的地貌动力响应. 科学通报, 1998, 43: 2315-2320]

27 Liu J K. Advanced Hydrobiology (in Chinese). Beijing: Science Press, 1999 [刘建康. 高级水生生物学. 北京: 科学出版社, 1999]

28 Meng Y F, Li C, Zhang J, et al. Community structure of macroinvertebrates and its relationship with environmental factors in different freshwater ecosystem function regions of Huntai River, China (in Chinese). J Dalian Fish Univ, 2018, 33: 77-85 [孟云飞, 李晨, 张吉, 等. 浑太河春季不同水 生态功能区大型底栖动物群落结构及其与环境因子的关系. 大连海洋大学学报, 2018, 33: 77-85]

29 Engle V D, Summers J K. Latitudinal gradients in benthic community composition in Western Atlantic estuaries. J Biogeogr, 1999, 26: 1007-1023

30 Mannino A, Montagna P A. Small-Scale spatial variation of macrobenthic community structure. Estuaries, 1997, 20: 159-173

31 Lin J. Importance of location in the salt marsh and clump size on growth of ribbed mussels. J Exp Mar Biol Ecol, 1989, 128: 75-86

32 Levin M L A. Are Spartina marshes a replaceable resource? A functional approach to evaluation of marsh creation efforts. Estuar Coast, 1991, 14: $1-16$

33 Dugan J E, Hubbard D M, Lastra M. Burrowing abilities and swash behavior of three crabs, Emerita analoga Stimpson, Blepharipoda occidentalis Randall, and Lepidopa californica Efford (Anomura, Hippoidea), of exposed sandy beaches. J Exp Mar Biol Ecol, 2000, 255: 229-245

34 Teal J M. Distribution of fiddler crabs in georgia salt marshes. Ecology, 1958, 39: 186-193

35 Silliman B R, He Q, Angelini C, et al. Field experiments and meta-analysis reveal wetland vegetation as a crucial element in the coastal protection paradigm. Curr Biol, 2019, 29: 1800-1806.e3

36 Chu T J. Secondary production of macrobenthos in salt marsh of the Yangtze River Estuary (in Chinese). Doctor Dissertation. Shanghai: Fudan University, 2013 [储忝江. 长江口盐沼湿地大型底栖动物次级生产力研究. 博士学位论文. 上海: 复旦大学, 2013]

37 Coverdale T C, Altieri A H, Bertness M D. Belowground herbivory increases vulnerability of New England salt marshes to die-off. Ecology, 2012, 93: 2085-2094

38 Callaway R M. Positive interactions among plants. Bot Rev, 1995, 4: 306-349

39 Xin P, Jin G, Li L, et al. Effects of crab burrows on pore water flows in salt marshes. Adv Water Resour, 2009, 32: 439-449

40 Botto F, Iribarne O. Contrasting effects of two burrowing crabs (Chasmagnathus granulata and Uca uruguayensis) on sediment composition and transport in estuarine environments. Estuar Coast Shelf Sci, 2000, 51: 141-151

41 McCraith B J, Gardner L R, Wethey D S, et al. The effect of fiddler crab burrowing on sediment mixing and radionuclide profiles along a topographic gradient in a southeastern salt marsh. J Mar Res, 2003, 61: 359-390

42 Iribarne O, Bortolus A, Botto F. Between-habitat differences in burrow characteristics and trophic modes in the southwestern Atlantic burrowing crab Chasmagnathus granulata. Mar Ecol Prog Ser, 1997, 155: 137-145

43 Jumars P A, Nowell A R M. Effects of benthos on sediment transport: Difficulties with functional grouping. Cont Shelf Res, 1984, 3: 115-130

44 Harvey G L, Henshaw A J, Brasington J, et al. Burrowing invasive species: An unquantified erosion risk at the aquatic-terrestrial interface. Rev Geophys, 2019, 57: 1018-1036

45 Crusius J, Bothner M H, Sommerfield C K. Bioturbation depths, rates and processes in Massachusetts Bay sediments inferred from modeling of ${ }^{210} \mathrm{~Pb}$ and ${ }^{239+240} \mathrm{Pu}$ profiles. Estuar Coast Shelf Sci, 2004, 61: 643-655

46 Chen Y Y. Effect of the zoobenthos activities on the seepage features of the sediment ground in the Yellow River estuarine area (in Chinese). Doctor Dissertation. Qingdao: Ocean University of China, 2006 [陈友媛. 生物活动对黄河口底土渗流特性的影响研究. 博士学位论文. 青岛: 中国海洋大学, 2006]

47 Meadows P S, Murray J M H, Meadows A, et al. Microscale biogeotechnical differences in intertidal sedimentary ecosystems. Geo Soc London Special Pub, 1998, 139: 349-366

48 Passarelli C, Olivier F, Paterson D M, et al. Organisms as cooperative ecosystem engineers in intertidal flats. J Sea Res, 2014, 92: 92-101

49 Schindler R J, Parsons D R, Ye L, et al. Sticky stuff: Redefining bedform prediction in modern and ancient environments. Geology, 2015, 43: 399402

50 Shroder J F. Treatise on Geomorphology. New York: Academic Press, 2013. 201-220

51 Tolhurst T J, Jesus B, Brotas V, et al. Diatom migration and sediment armouring-An example from the Tagus Estuary, Portugal. Hydrobiologia, 2003, 503: 183-193 
52 Paterson D M, Daborn G R. Sediment stabilisation by biological action: Significance for coastal engineering. In: Peregrine D H, Loveless J H, eds. Developments in Coastal Engineering. Bristol: University of Bristol Press, 1991. 111-119

53 Gerbersdorf S U, Wieprecht S. Biostabilization of cohesive sediments: Revisiting the role of abiotic conditions, physiology and diversity of microbes, polymeric secretion, and biofilm architecture. Geobiology, 2015, 13: 68-97

54 Paterson D M, Aspden R J, Visscher P T, et al. Light-dependant biostabilisation of sediments by stromatolite assemblages. PLoS One, 2008, 3: e3176

55 Gerbersdorf S U, Jancke T, Westrich B. Physico-chemical and biological sediment properties determining erosion resistance of contaminated riverine sediments-Temporal and vertical pattern at the Lauffen reservoir/River Neckar, Germany. Limnologica, 2005, 35: 144

56 Tolhurst T J, Consalvey M, Paterson D M. Changes in cohesive sediment properties associated with the growth of a diatom biofilm. Hydrobiologia, 2008, 596: 225-239

57 Stone M, Krishnappan B G, Emelko M B. The effect of bed age and shear stress on the particle morphology of eroded cohesive river sediment in an annular flume. Water Res, 2008, 42: 4179-4187

58 Davis C A, Pyrak-Nolte L J, Atekwana E A, et al. Microbial-induced heterogeneity in the acoustic properties of porous media. Geophys Res Lett, 2009, 36: 147-148

59 Zhao H M, Tang L Q, Mao Y Y, et al. Review of impact on coastal sediment from intertidal microbial system (in Chinese). J Waterway Harbor, 2014, 35: 445-452 [赵慧明, 汤立群, 毛远意, 等. 潮间带微生物系统对海岸泥沙影响研究进展. 水道港口, 2014, 35: 445-452]

60 Fang H W, Zhao H M, He G J, et al. Experiment of particles' morphology variation after biofilm growth on sediments (in Chinese). J Hydraul Eng, 2011, 42: 30-35 [方红卫, 赵慧明, 何国建, 等. 泥沙颗粒生长生物膜前后表面变化的试验研究. 水利学报, 2011, 42: 30-35]

61 Fang H W, Shang Q Q, Fu R S, et al. Experimental study of the effect of biofilm formation on sediment incipient motion: II. Incipient velocity calculation (in Chinese). Adv Water Sci, 2011, 22: 9-14 [方红卫, 尚倩倩, 府仁寿, 等. 泥沙颗粒生长生物膜后起动的实验研究一一 II. 起动流 速计算. 水科学进展, 2011, 22: 9-14]

62 Holger S, Moritz T, Silke W, et al. The effect of light intensity and shear stress on microbial biostabilization and the community composition of natural biofilms. Res Rep Biol, 2018, 9: 1-16 


\title{
The roles of biological factors in coastal sediment transport: $A$ review
}

\author{
Zheng Gong ${ }^{1}$, Xindi Chen ${ }^{1,2}$, Zeng Zhou ${ }^{1,3^{*}}$, Ran $\mathrm{Ge}^{1}$, Xue Chen ${ }^{1}$, Xiping $\mathrm{Yu}^{2} \&$ Changkuan Zhang ${ }^{1}$ \\ ${ }^{1}$ Jiangsu Key Laboratory of Coast Ocean Resources Development and Environment Security, HoHai University, Nanjing 210098, China; \\ ${ }^{2}$ State Key Laboratory of Hydroscience and Engineering, Department of Hydraulic Engineering, Tsinghua University, Beijing 100084, China; \\ ${ }^{3}$ State Key Laboratory of Hydrology-Water Resources and Hydraulic Engineering, Hohai University, Nanjing 210098, China \\ * Corresponding author, E-mail: zeng.zhou@hhu.edu.cn
}

Coastal sediment transport and geomorphological evolution are important scientific focuses in the research field of landocean interaction. The feedback between various factors such as hydrodynamics, extreme climate conditions, biological effects, human activities results in complex ecological and environmental characteristics and poses a great challenge to the development and protection of coastal areas. Closely related to the evolution of coastal geomorphology, the stability of coastal sediment is mainly affected by sediment properties and associated dynamics. Traditionally, it is considered that the change of sediment characteristics and dynamics is greatly driven by physico-chemical factors such as particle size distribution, water content and mineral composition and so on. However, the impact of various active biological factors is generally neglected. Over the past decades, with the deepening understanding of coastal ecological environment, more attention has been paid to the critical roles of biological factors in coastal systems. A large amount of field observation data and laboratory-controlled experiments demonstrated that organisms inhabiting coastal areas contribute a lot to sediment erosion, transportation, deposition, consolidation processes in direct or indirect ways. For example, the cohesion between sediment particles could be increased by microorganisms through secreting extracellular polymeric substances (EPS) so as to enhance sediment stability; salt-tolerant vegetation has an ability to improve the stability of the sediment bed by capacity of sediment retention and reducing hydrodynamic force; the structure of sediment bed could be destroyed by coastal benthos through feeding and burrowing, which would lead to the failure of the bed. On the one hand, these multiple biological effects endow sediment particles with "biological characteristics", gradually modifying sediment characteristics and sediment dynamics; on the other hand, they try to strengthen or weaken external erosive forces by remolding sedimentary or dynamic environment. Finally, a more stable or unstable coastal biological sedimentological system different from the traditional physico-chemical sedimentological system is formed as a result of the interaction between these diverse biological factors. This enhances the cognition of traditional coastal sediment dynamics, and relevant research is gradually becoming a research hotspot. Understanding the roles of biological effects in coastal sediment dynamics and evolution of coastal geomorphology is helpful for enriching theory of coastal sediment dynamics, promoting the intersection of coastal dynamics, sediment dynamics and ecological environmentology, and promoting the development of the research field "biomorphodynamics". Focusing on the role of biological factors in the coastal sediment dynamics, this paper reviews the state-of-the-art research on the distribution characteristics of salt-tolerant vegetation, benthos and microorganisms in the coastal area, their contribution to coastal sediment movement as well as the underlying mechanisms. At present, the research on the influence of biological factors on the coastal sediment dynamics is still in the initial stage, and many of the research conclusions are relatively loose, mostly qualitative at macro-level, and a complete theoretical framework has not yet been established. The mechanism of the interaction between coastal sediment and biology, as well as the establishment of simulation models of sediment dynamics and morphological evolution will be the focus of future research.

coastal zone, biostabilisation of sediment, coastal vegetation, benthos, intertidal microorganism doi: 10.1360/TB-2020-0291 